\title{
建築様式，住まい方の変化が室内温熱環境に及ぼす影響 一八重山郡竹富島におけるパッシブ環境制御手法に関する研究（その 2 ) - EFFECTS OF THE CHANGE IN ARCHITECTURAL STYLES AND LIFESTYLE ON INDOOR THERMAL ENVIRONMENT
}

Passive environmental control methods on Taketomi Island, Yaeyama (Part 2)

\author{
井上大嗣*, 白石靖幸**, 中野淳 太*** \\ Daishi INOUE, Yasuyuki SHIRAISHI and Junta NAKANO
}

\begin{abstract}
The purpose of this study is to clarify the effects of change of architectural style and open time of the openings on indoor thermal environment in the traditional vernacular house of Taketomi Island. The comparison measurement of indoor thermal environment and CFD analysis of cross ventilation performance in traditional vernacular are conducted. The following results were obtained: 1) When the traditional opening pattern (opening during the day, closing during the night) were reproduced in old Yonaguni house which leaves a traditional architectural style, SET* in the daytime became low about $2^{\circ} \mathrm{C}$ as compared with the other repaired traditional vernacular. Indoor wind velocity contributed to the fall of the effective temperature most. 2) When openings are closed in old Yonaguni house at night, since the airtight performance of the sashes are low and there is also almost no internal load, SET ${ }^{*}$ also becomes low about $1-2^{\circ} \mathrm{C}$ at night comparing with other vernaculars. 3) According to CFD analysis, in existing traditional vernaculars, since opening area is halved with the installation of aluminium sashes or podium, PFR/Vp and kinetic energy $\mathrm{KE}$ are falling to about $25 \%$ and $50 \%$ respectively through all wind directions, comparing with the old Yonaguni houses. Especially, the influence by installation of aluminium sashes is larger than that of podium.
\end{abstract}

Keywords: Taketomi Island, Traditional Vernacular House, Thermal Environment, Natural and Cross Ventilation, CFD Analysis 竹富島，伝統的民家，温熱環境，自然換気・通風，CFD解析

\section{1. 序}

近年、地球温暖化の顕在化に伴い、パッシブ手法と言ったエネルギ 一消費を伴わない環境制御技術が注目を集めている。日本にはそれら パッシブ技術を有する伝統的な建物が数多く存在する。本研究では、 高温多湿地域におけるパッシブ環境制御手法に関する研究の一環と して、琉球地方における伝統的集落・民家形態を残寸八重山郡竹富集 落を対象とし、集落スケール、民家スケールでの暑熱環境緩和・防風 効果を解明することを目的として、既報(その 1) ${ }^{1}$ )では、竹富集落に おける夏季の屋内外の温熱環境等の測定結果について報告した。集落 の景観要素である石垣や白砂の路地による屋外の暑熱環境緩和効果 等の幾つかの優位性は確認できたものの、対象民家内の温熱環境に関 しては、改修により本来の伝統的民家とは形態・仕様が異なっており、 また開口部の開閉等に代表される住まい方が変化することによって 1)、室内の自然換気・通風量が低下し、それに伴い室内温熱環境も変 化（悪化）しているものと推測された。従って、本報では伝統的民家 本来の室内温熱・空気環境の検証を目的として、追加実測として、原 型を残寸伝統的民家(図 1 旧与那国家民家) と改修が施された現状の 伝統的民家(図 1 民家 $\mathrm{A}$ 及び $\mathrm{B}$ ) を対象とした室内温熱環境の測定を 行ったため、その比較・検討結果について示寸注 1)。特に、民家内の 風環境や自然換気量に関しては、今回の実測では詳細を把握すること ができなかったため、数值シミュレーションによるアプローチとして、
CFD (Computational Fluid Dynamics) 解析によりアルミサッシや腰壁 の設置等による開口面積の縮小といった改修・民家形態の変化が室内 の自然換気・通風性状にどのような影響を与えるかを詳細に検討する。 伝統的民家やヴァナキュラー建築を対象とした環境性能評価は多数 試みられており 2-4)、室内温熱環境や換気量評価には CFD 解析が活用 されるに至っている。しかし竹富島の民家のように琉球地方の伝統的 民家を対象とした研究・解析事例はなく、また近代化に伴った建築形 態や住まい方の変化による室内温熱環境の変化を検証しようとする 研究は見られない。

\section{2. 実測対象}

\section{2-1 竹富島における伝統的民家}

竹富島の伝統的な民家は貫屋と呼ばれる架工法によって成り、敷地 中央に母屋 (フーヤ) と台所棟 (トーラ)の 2 棟を南向きに配する構成 が一般的である(図 1)。母屋正面には低く深い軒によりアマ八ジ空間 がつくられており、屋根は赤瓦莫きの寄棟屋根で敷地は石垣で囲まれ ている。屋敷内には母屋より丈の高いフクギが数本から数十本植えら れており、これらは防風、日射遮蔽の役割を果たす5)。

\section{2-2 現状の民家における建築様式の変化}

本来の伝統的民家では、母屋においてはガラス戸を用いず、昼間は 開放されたままで、夜間や破天の時には雨戸を立てていたが、現在で

\footnotetext{
本論文は既に発表した文献12），13）を加筆・修正したものである

* (株)日建設計工修

** 北九州市立大学国際環境工学部 准教授 ·博士 (工学)

*** 東海大学工学部建築学科 講師 · 博士 (工学)
}

Nikken Sekkei Co., Ltd., M. Eng.

Assoc. Prof., Faculty of Environmental Engineering, The Univ. of Kitakyushu, Dr. Eng. Lecturer, Department of Architecture and Building Engineering, Tokai University, Dr. Eng. 
表 1 竹富集落における生活様式及び建築様式の変化と原因 ${ }^{1)}$

\begin{tabular}{|c|c|c|}
\hline \multicolumn{2}{|r|}{ 生活様式・建築様式の変化 } & 原因 \\
\hline (1) & $\begin{array}{c}\text { 気密性の向上 } \\
\text { (アルミシッシ設置等) }\end{array}$ & $\begin{array}{l}\text { 冷房の使用 } \\
\text { 観光客の増加による防犯意識の向上 } \\
\text { 台風への防御 }\end{array}$ \\
\hline (2) & トーラの機能消失 & $\begin{array}{l}\text { 茅葺から瓦蓦への屋根の変化 } \\
\text { (火事の危険性低減) } \\
\text { 家電製品等の調理器具の使用 } \\
\text { (利便性・排煙等の問題) }\end{array}$ \\
\hline (3) & 日中開口部の閉鎖 & $\begin{array}{l}\text { 冷房の使用 } \\
\text { 人や車の往来に伴った室内への白砂の埃の } \\
\text { 侵入を防ぐ } \\
\text { 観光客増加に対するプライバシー保護 }\end{array}$ \\
\hline (4) & $\begin{array}{l}\text { フクギの下枝を } \\
\text { 剪定しない:22) }\end{array}$ & 上記(3)の原因に対応 \\
\hline
\end{tabular}

表 2 各民家の開口部の開閉パターン

\begin{tabular}{|c|c|c|c|}
\hline 民家 & 日付 & 日中 & 夜間 \\
\hline \multirow[t]{4}{*}{ 1）旧与那国家民家 } & $9 / 3$ & 半開 & 閉鎖 \\
\hline & $9 / 4$ & 開放 & 閉鎖 \\
\hline & $9 / 5$ & 閉鎖 & 開放 \\
\hline & $9 / 6 \sim 9 / 7$ & 開放 & 開放 \\
\hline 2）民家 A & $9 / 2 \sim 9 / 7$ & 開放 & 閉鎖 \\
\hline 3）民家 $\mathrm{B}$ & $9 / 2 \sim 9 / 7$ & 閉鎖 & 閉鎖 \\
\hline
\end{tabular}

はほとんどの家屋において、台風への防御、防犯性、冷房の使用等の 面から開口部にはガラス戸が設置されている。加えて、伝統的建築様 式の木造民家においても比較的新しいものには腰壁やアルミサッシ の設置等による開口面積の縮小も見られる。本来の伝統的民家は、戸 を全て戸袋に収納することにより、開口部全面を開放可能な形態とな っている。その他にも表 1 に示寸ように生活様式や建築様式にも変化 が見られる。特に開口部の開閉に関しては日中開口部を閉じている民 家も少なからずあり、本来の開放的な造りである伝統的民家が持つ通 風性能を発揮しているとは言い難い注2)。

\section{2-3 測定対象民家}

測定対象民家を図 1 に示す。測定対象の民家は既報(その1 1$)^{1)}$ にお いて測定を行った民家 $\mathrm{A}$ 、民家 B に加え、伝統的民家の原型を留めて いる民家として旧与那国家を対象に室内温熱環境測定を行った。既報 $(\text { その } 1)^{1)}$ において測定を行った民家Cに関しては、今回は測定を行 っていない。旧与那国家は重要文化財に指定されており、現在、居住 者はおらず注 ${ }^{3)}$ 、島内の定期的な集会等に活用されている。民家 $\mathrm{A} の$ 居住者は高齢の夫婦であり、日中南面と西面の開口部を開放し、夜間 は閉鎖している。アルミサッシ等の設置により、開口時の開口面積は 旧与那国家より小さく、台所はフーヤ内にあり、トーラは現在倉庫と して使用されている。民家Bの居住者は高齢の女性 1 人であり、開口 部は日中・夜間共に閉じたままの状態が多い。民家 $\mathrm{A}$ と同様に台所は フーヤ内にあり、トーラは倉庫として使用されている。民家 $\mathrm{A} ， \mathrm{~B}$ 共 に泠房が設置されており、測定期間中は民家 Aで就寝前に使用してい る。

\section{3. 実測概要}

民家内の温熱環境測定のためアメニティメータ (AM-101 京都電子 工業)により気温、湿度、MRT、風速の測定を行い、これにより SET* を算出した。なお、前回の測定 ${ }^{1)}$ の際に、民家 A 及び B では居間と他 の部屋との平均温度の差があまり見られなかったため、今回の測定で
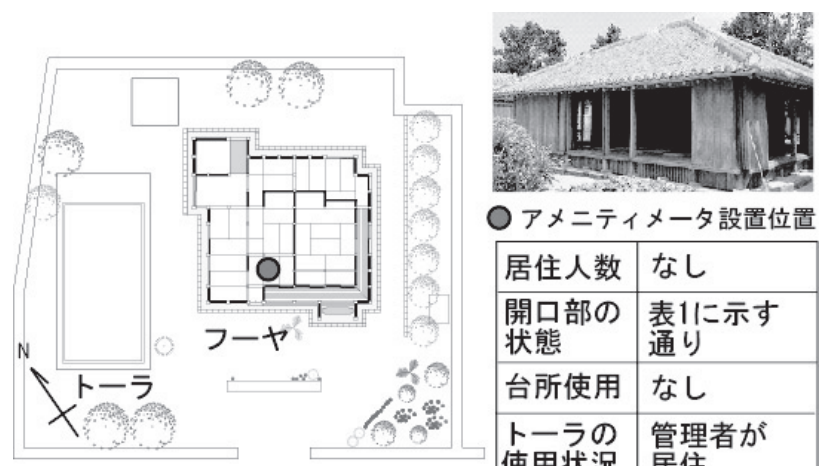

1）旧与那国家民家(原型を残寸伝統的民家)

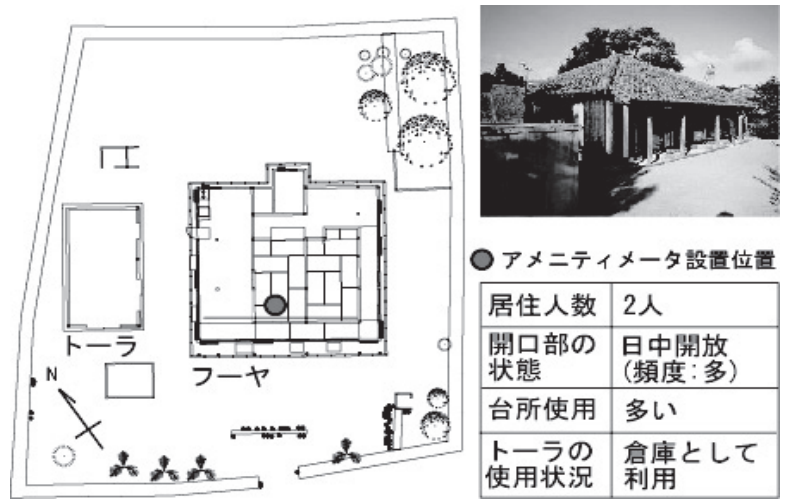

2）民家 A(改修が施された現状の伝統的民家(1)

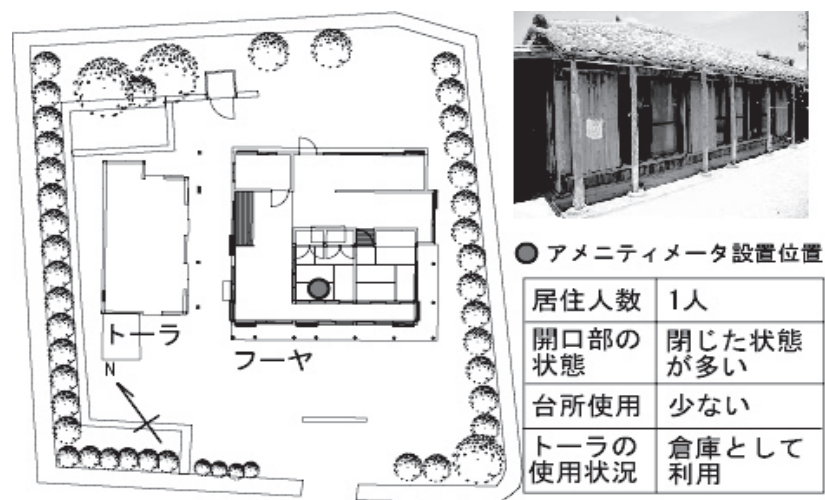

3）民家 B(改修が施された現状の伝統的民家(2)

図 1 測定対象民家図面

は居間以外の部屋の測定を行っていない。SET算出時の着衣量及び代 謝量はそれぞれ $0.5 \mathrm{c} 10$ 、1. 0 met とした。図 1 に示寸ポイントの床上 高さ $0.6 \mathrm{~m}$ (座位体中心)に設置し、30 分間隔で測定を行っている。そ の他、旧与那国家民家の敷地内には、百葉箱に入れた温湿度計を一力 所設置し、屋外温湿度の測定も行っている。測定期間は 2008 年 $9 / 2$ 18:00 9/8 12:00 で、期間中の天候は 9/2〜3 までが晴り、 9/4 以降 は晴れであった。測定期間中の外気温、平均風速、日射量を図 2 に示 す。前回の測定 ${ }^{1)} に て 、$ 竹富島に屋外気象観測装置を設置して測定し た気象データと石垣島の地方気象台のデータ(気象庁)がほぼ一致し たため、今回は石垣島地方気象台のデータを用いた。

実測期間中の各民家の開口部の開閉パターンを表 2 に示寸。旧与那 国家民家に関しては管理者の許可の下、表 2 に示寸ように日中夜間の 開口部の開閉パターンを変化させて測定を行った。9/3 は昼夜ほぼ閉 
鎖状態注 4)、9/4〜9/5 は昼夜のどちらかを開放、9/6〜 9/7 は昼夜開放 した状態で測定を行った。伝統的民家の本来の運用方法としては、 $9 / 4$ の日中開放、夜間閉鎖のパターンが対応する。民家 A 及び B の開口部 の開閉は、居住者任せではあるが、概ね表 2 に示すような運用を行っ ていることを確認している。

\section{4. 実測結果}

\section{4-1 SET*}

図 3 に各民家における SET*の時系列変化を示す。実測期間を通じた 傾向として、各民家とも昼間の時間帯は $30 \sim 34^{\circ} \mathrm{C}$ 程度、夜間の時間 帯は $26 \sim 32^{\circ} \mathrm{C}$ 程度で推移している。昼間の時間帯においては開口部 を常に閉じている民家 B が比較的高い值を示しており、民家 A と旧与 那国家はそれより低い值で推移している。特に夜間の時間帯において は各民家間での差異が昼間よりも大きくなっている。また民家 A にお いて 21:00〜24:00 の時間帯に室温が著しく低下しているが、これは 就寝前に冷房を使用しているためである。

次に一日単位の傾向として、9/4の旧与那国家では、伝統的な住ま い方（日中開放、夜間閉鎖）を再現しており、他の民家と比較して日 中の SET*が $2{ }^{\circ} \mathrm{C} ほ と ゙$ 低い。民家 $\mathrm{A}$ においても同様の住まい方をしてい るが、本来の民家形態と比較すると開口面積が半減している等の理由 により十分な室内風速が得られておらず (図 5 参照)、開口部を閉鎖 している民家 B と日中の SET*に殆ど差がない。夜間になり全ての民家 で開口部を閉鎖しているが、旧与那国家では他の民家と比較して、建 具の気密性能が低く夜間の換気量も多いものと推察され、また内部発 熱量注6) も殆じないため、SET*は夜間においても $1 \sim 2{ }^{\circ} \mathrm{C}$ 程度低くなる。

9/5 の旧与那国家では、前日夕方から当日の夕方にかけて開口部を 閉鎖して、夕方以降開放しているが、日中は各民家共に室内風速はほ ぼ $0.1 \mathrm{~m} / \mathrm{s}$ 以下となり、SET*は 3 つの民家でほぼ一致する結果となっ た。また、旧与那国家では夕方の開口部の開放と共に $\mathrm{SET}^{*} か ゙ ~ 4{ }^{\circ} \mathrm{C}$ 程度 低下している。9/4 と 9/5のSET*の結果を比較することにより、室内 風速が体感温度の低下に大きく寄与していることが分かる。その他の 要因として自然換気・通風による日射熱や内部発熱の排出効果も考え られるが、各民家の日中の室温にあまり差がない点（図 6）や民家内 の平均放射温度が室温と同程度に推移するといった結果 ${ }^{1)}$, 注7) から判 断すると、体感温度の低下には室内風速の寄与が最も大きいものと推 察され、これは蒸暑地域における一般的な知見と一致する。

9/6〜7 にかけて旧与那国家では、常時開口部を開放しており、昼 夜を問わず他の民家と比較して、SET*が最大で $4{ }^{\circ} \mathrm{C}$ 程度低くなる。夜 間から朝方にかけては、冷房を行っている民家Aほどではないが、こ れに近い值まで SET*が低下している。

図 4 に各民家内温度、SET*の平均值及び変動幅を示す。旧与那国家 の開口部の開閉パターンの異なる $9 / 3,4,5,6$ の 4 日間の結果をそれぞ れ室内温度を左側に SET右側に示す。 $9 / 3$ は量りで日射量が少なか ったため、各民家共に変動が小さい。9/4 以降は旧与那国家において 開口部を開放していたため他の民家と比較すると平均温度、SET*共に 低い傾向にあることが確認できる。旧与那国家において伝統的民家本 来の開口部の開閉パターンを再現した $9 / 4$ で比較すると、現状の民家 は開口面積の減少に伴った通風性能の低下 (民家A) や開口部を常時閉 鎖するといった住まい方の変化 (民家 B) 等の理由により、夏季室内の 体感温度が約 $1 \sim 2^{\circ} \mathrm{C}$ 程度 (平均值) 高くなることが本実測により確

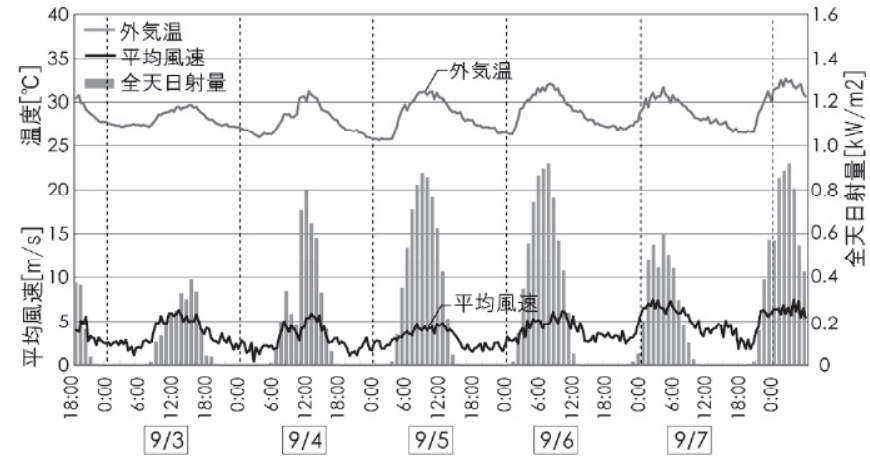

図 2 外気温·平均風速・日射量（石垣島地方気象台観測地）

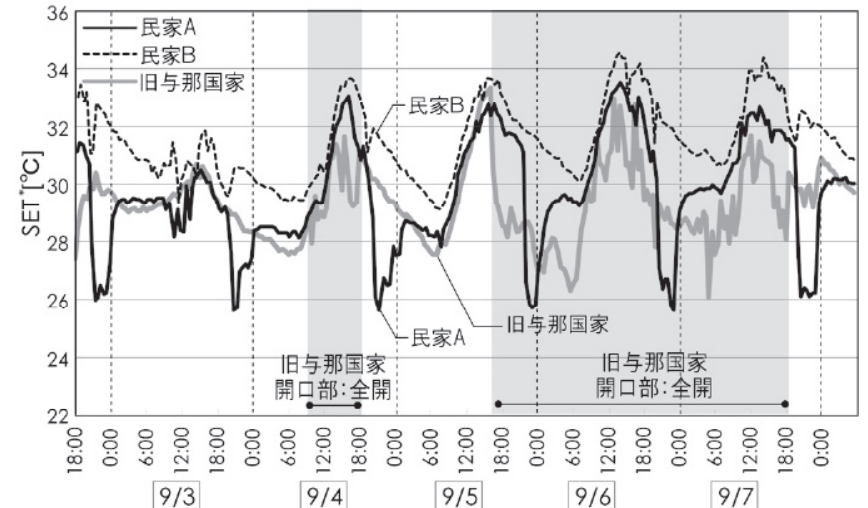

図 3 各民家の SET*の時系列変化注5)

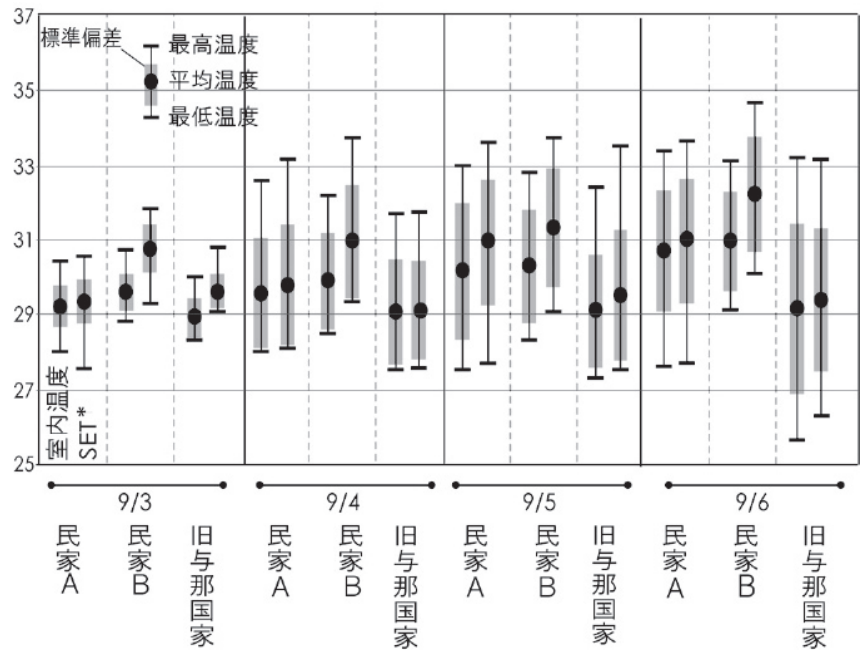

図 4 各民家内温度、SET*の平均值及び変動幅注 8 )

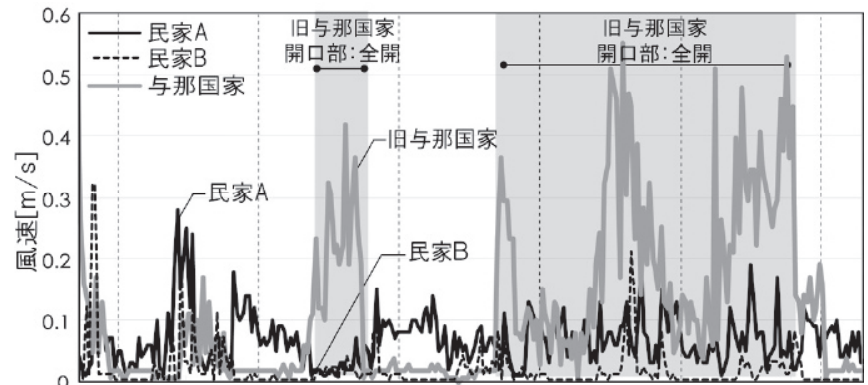

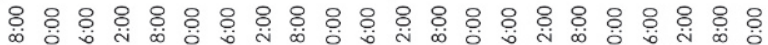

$9 / 3$ 9/4 9/5 9/6

図 5 室内風速の時系列変化 


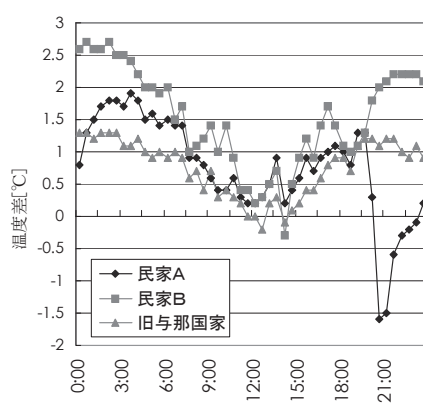

1) $9 / 3$

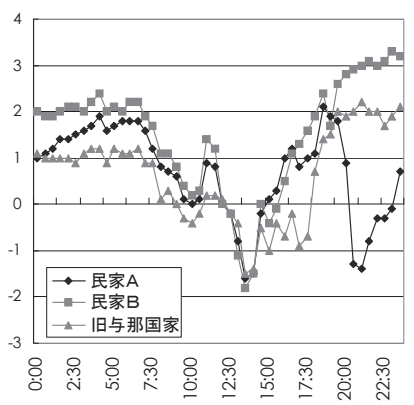

2) $9 / 4$

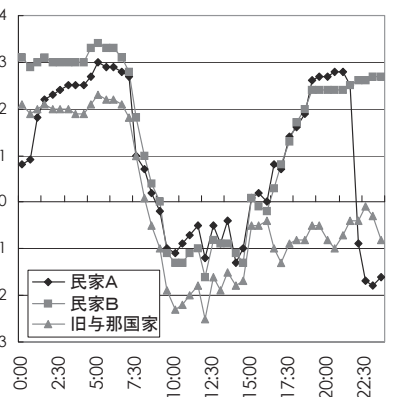

3) $9 / 5$

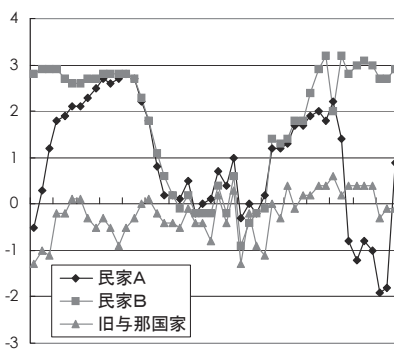

电兽 8 郘

4) $9 / 6$

図 6 室内外温度差（室内温度一外気温度） 注9)

認できた。また、夜間の風通しを意図した $9 / 6$ や $9 / 7$ のデータと比較 すると、約 $2 \sim 3^{\circ} \mathrm{C}$ 程度（平均值）高くなることが示唆された。

\section{4-2 室内風速}

図 5 に室内風速の時系列変化を示す。民家 $\mathrm{A}$ では日中開口部を開放 していたため、0.1〜0. $3 \mathrm{~m} / \mathrm{s}$ 程度の風速が確認できる。また夜間にお いては開口部を閉鎖していたが、冷房、扇風機を使用しているため $0.1 \mathrm{~m} / \mathrm{s}$ 程度の風速が確認できる。民家 B ではほぼ全時間帯において 開口部を閉じていたため、室内風速は $0 \mathrm{~m} / \mathrm{s}$ に近い值となっている。 旧与那国家では、 $9 / 4$ の 9:00〜 18:00、9/5の 18:00〜 9/7 の 18:00の 期間で開口部を全て開放して測定を行っているため、0.1〜0. $5 \mathrm{~m} / \mathrm{s}$ 程 度の風速となっている。図 3 の SET*の結果とも概数対応する。図 2 の 屋外の平均風速データから分かるとおり、外部風は夜間低くなる傾向 にあるが、これに伴い室内風速も $0.1 \mathrm{~m} / \mathrm{s}$ 程度に低下寸る。

\section{4-3 内外温度差}

図 6 に各民家の室内外温度差を示す。まず、 $9 / 3$ は旧与那国家にお いて昼間開口部を半開、夜間に全閉の状態であった。各民家共に日中 は外気温に近い值を示し、夜間において $1.0 \sim 2.5^{\circ} \mathrm{C}$ 程度高い值とな っている。各民家間では図 3 の SET*の傾向と対応し、民家B、民家 A、 旧与那国家の順で外気温との温度差が大きい傾向にある。9/4 は旧与 那国家において昼間開口部を全開、夜間に全閉の状態であったが、ほ ぼ $9 / 3$ と同様な傾向となっている。9/5 は旧与那国家では開口部を昼 間閉鎖、夜間開放していたが、日中外気温度が $30^{\circ} \mathrm{C}$ を超え、室内外 温度差は、日中マイナスとなる時間帯もある。開口部を開放していた 夜間においても外気温に近い值、若しくは低い值となっており、他の 民家に比べて $3 \sim 4^{\circ} \mathrm{C}$ 程度低い。9/6 は旧与那国家では終日開口部を開 放しており、全時間帯で外気温との差はほぼ $0{ }^{\circ} \mathrm{C} て ゙$ 推移している。夜 間の時間帯においても $9 / 5$ と同様他の民家に比べて $2 \sim 3^{\circ} \mathrm{C}$ 程度低い 值となっている。以上より、夜間の外気導入により更なる室内温度の 低下が期待できることが示唆された。

\section{CFD 解析の概要}

上記実測調査では、伝統的建築様式を残寸民家と改修が施された民 家に対して室内温熱環境の比較・検証を行い、民家の自然換気・通風 性能の低下が、室内温熱環境を悪化させている一つの要因である可能 性が示唆された(例えば、開口部の開閉パターンの同じ $9 / 4$ の日中の 旧与那国家と民家 $\mathrm{A}$ の比較)。しかし、今回の実測では、民家内の風 速測定は居間の 1 点のみでしか行っておらず、民家の自然換気・通風 性能を評価するにあたっては不十分である。また扇風機の使用等、人 為的な要因による影響も否めない。換気量評価に関しては、トレーサ 一ガス法や圧力差法等の現地実測による測定も考えられるが、対象民
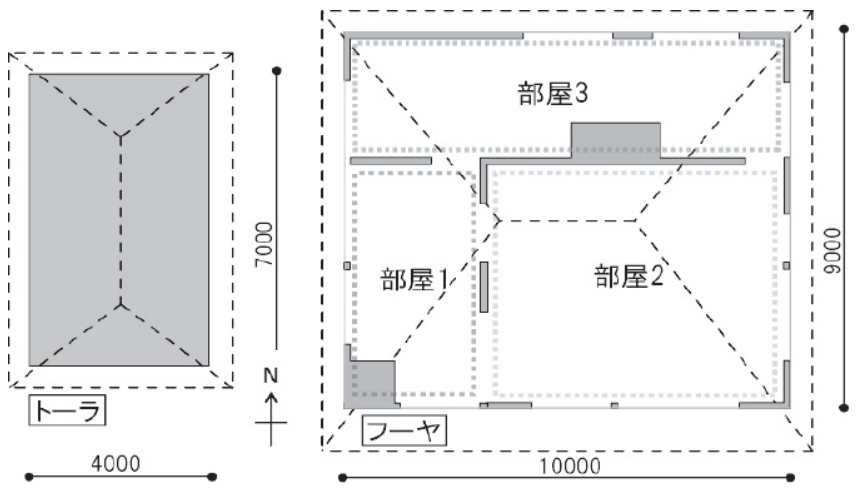

図 7 解析モデル平面図

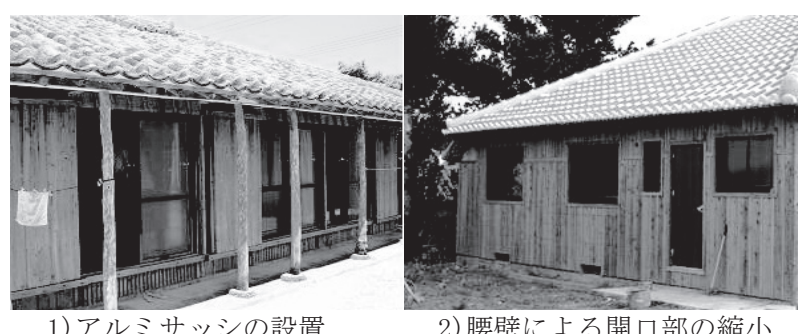

写真 1 建築様式の変化

家の開放度が高く、外気の流入流出経路も複雑であるため、正確な換 気量の測定は困難である。このため、本研究では CFD 解析を採用する。 CFD 解析では、アルミサッシや腰壁の設置に伴った “民家の形状変 化”に関するケーススタディを実施し、改修や建築様式の変化による 民家の通風性能の低減効果の検証を行う。

\section{5-1 解析対象とモデル化}

竹富島にみられる伝統的民家のモデル化は、伝統的建築形態を残 寸旧与那国家 (重要文化財指定)の図面を基に再現している。図 7 に解 析モデルの平面図を示す。室内は間仕切りを全て開けた状態を想定し、 三番座を部屋 1 とし、一番座、二番座を合わせて部屋 2 とし、裹座を 部屋 3 としてそれぞれの部屋の通風性能を検討する。

\section{5-2 解析ケース}

既報(その 1) ${ }^{1)}$ で示した通り、現状における伝統的民家では、アル ミサッシの設置や開口部の縮小等の建築様式の変化が見られる(写真 1)。これらは開口面積の減少に繋がるものと考えられ、本来開放的造 りである建築椂式の通風性能を低下させる要因となっていると推察 される。よって本解析では、現状の改修が施されている民家に見られ るアルミサッシと腰壁の設置による開口部の縮小を再現し、これらの 室内換気、通風性能への影響を検討寸る。解析ケースを図 8 に示す。 
Case 1 を本来の伝統的民家の建築様式を想定し、Case2 では腰壁によ る開口部の縮小を考慮、Case3 ではアルミサッシの設置を考慮、Case4 では Case2、Case3 の両条件を考慮して解析を行う。また各風向にお ける室内通風性状を把握するため、各ケースにおいて計 16 風向で解 析を行う。

\section{5-3 解析条件}

水平方向 $100 \mathrm{~m}(\mathrm{X}) \times 100 \mathrm{~m}(\mathrm{Y})$, 鉛直方向 $30 \mathrm{~m}(\mathrm{Z})$ の解析領域の中央に 民家を配置し、民家内外を一体的な解析空間として、流れ場及び濃度 場の解析を行う。解析条件を表 3 に示す。流入境界は敷地内風速測定 結果より得られた平均風速(高さ $2.0 \mathrm{~m}$ にて風速 $0.59[\mathrm{~m} / \mathrm{s}])^{1}$ )を使用し 鉛直風速分布は $1 / 4$ べき乗則と仮定した。換気・通風性能の評価のた め污染物質を室内空間から一様に $1.0 \mathrm{~kg} / \mathrm{s} \cdot \mathrm{m}^{3}$ 発生させ、濃度分布を 算出する。乱流モデルは改良 $\mathrm{k}^{-} \varepsilon$ モデル ${ }^{6)}$ を使用する。

\section{5-4 CFD 解析の予測精度の検証}

本解析を行うに当たって、CFD 解析を民家内の換気量評価に適応し た際の予測精度の検証のため、風洞実験を対象とした事前解析を行っ た。解析対象は文献 (7) の独立住宅を模擬したモデルであり、風洞実 験と同様に風向を流入側開口法線方向に対して $0^{\circ} \sim 75^{\circ}$ の計 6 ケー スで行った。CFD 解析の境界条件、乱流モデル等は Case 1 と同様とし た。污染物質の発生、濃度分布の測定は風洞実験と同条件で行い、換 気回数の算出を行った。風洞実験と CFD 解析の結果を図 9 に示寸。CFD 解析の結果は風洞実験の結果とほぼ一致しており、実際の民家モデル とは建物形状が異なるものの、CFD 解析により実用上、十分な予測精 度で室内の換気量を評価できることを確認した。

\section{5-5 民家内の換気 ·通風性状の評価手法}

民家内の換気・通風性状の評価に際しては、民家内一貫流もしくは 民家内で発生する熱エネルギーの排出効率、及び気流による体感温度 の低減効果に着目し、以下の 2 つの指標を用いる。

(1) 局所排出換気回数 $\mathrm{PFR} / \mathrm{V}_{\mathrm{p}}^{8)}$

PFR (Purging Flow Rate) は通風性状を評価する指標であり、空間内で 一様に発生させた污染物質発生量 $\mathrm{q}_{\mathrm{p}}[\mathrm{kg} / \mathrm{s}]$ を局所領域内の污染物質 空間平均濃度 $\mathrm{C}_{\mathrm{p}}\left[\mathrm{kg} / \mathrm{m}^{3}\right]$ で除したもの $\left(\mathrm{PFR} /=\mathrm{q}_{\mathrm{p}} / \mathrm{C}_{\mathrm{p}}\left[\mathrm{m}^{3} / \mathrm{s}\right]\right)$ として定義 される実質的な換気量である。局所排出換気回数 $P F R / V_{p}$ は実質的な 換気量を空間の体積 $\mathrm{V}_{\mathrm{p}}$ で除して算出される実質的な換気回数である。 (2) 運動エネルギーKE ${ }^{8)}$

室内の平均運動エネルギーは暑熱時における体感温度の低下能力を 表寸物理量と考えられる。平均流の速度 $(u, v, w)[\mathrm{m} / \mathrm{s}]$ 、乱流エネルギ 一 $(k)\left[\mathrm{m}^{2} / \mathrm{s}^{2}\right]$ より、室内空間の平均運動エネルギー $(K E)\left[\mathrm{m}^{2} / \mathrm{s}^{2}\right]$ を次式 で計算する。

$$
K E=\frac{1}{V_{p}} \iiint_{\text {Indoor }}\left[\frac{1}{2} \times\left(u^{2}+v^{2}+w^{2}\right)+k\right] d V
$$

\section{6. 解析結果}

\section{6-1 夏季卓越風向時 (南風向) の結果}

図 10 に高さ $1.1 \mathrm{~m}$ (体中心)での風速分布、並びに各室での PFR/Vp 及び運動エネルギーを各ケース毎にそれぞれ示す。ここでは竹富島の 夏季の卓越風向である南風向時の結果を示している。

Case1 の風速分布では、前面に位置する部屋 1 、部屋 2 において全 体的に流速が速く、PFR $/ \mathrm{V}_{\mathrm{p}}$ 、運動エネルギー双方においても高い值と なっている。開口部を開放する日中においては居住者は三番座である
表 3 解析条件

\begin{tabular}{|l|l|}
\hline 解析領域 & $100 \mathrm{~m}(\mathrm{X}) \times 100 \mathrm{~m}(\mathrm{Y}) \times 30 \mathrm{~m}(\mathrm{Z})$ \\
\hline 流入境界 & $\begin{array}{l}\mathrm{U}=\mathrm{U}_{\mathrm{d}}\left(\mathrm{Z} / \mathrm{Z}_{\mathrm{o}}\right)^{1 / 4} \\
\varepsilon=\mathrm{C}_{\mu} \mathrm{k}_{\mathrm{in}}{ }^{1.5} \mathrm{U}_{\mathrm{d}} / 4\left(\mathrm{C}_{\mu} \mathrm{k}_{\mathrm{in}}{ }^{0.5}\right) \mathrm{Z}_{\mathrm{o}}{ }^{0.25} \mathrm{Z}^{0.75} \\
\mathrm{k} \text { は風洞実験值 }{ }^{9)}\end{array}$ \\
\hline 流出境界 & 圧力境界条件 \\
\hline 上空境界 & フリースリップ \\
\hline 地表面境界 & 一般化対数則 \\
\hline 乱流モデル & 改良 $\mathrm{k}^{-\varepsilon}$ モデル ${ }^{6)}$ \\
\hline メッシュ分割 & $151(\mathrm{X}) \times 115(\mathrm{Y}) \times 63(\mathrm{Z})$ \\
\hline その他 & $\begin{array}{l}\text { 民家内領域において污染物質を } 1.0 \mathrm{~kg} / \mathrm{m}^{3} \mathrm{~s} \text { で } \\
\text { 一様発生させ定常濃度分布を算出する。 }\end{array}$ \\
\hline
\end{tabular}

$\left(\mathrm{U}:\right.$ 流入風速 $[\mathrm{m} / \mathrm{s}] \quad \mathrm{Z}$ :鉛直方向座標 $[\mathrm{m}] \mathrm{k}$ : 乱流エネルギー $\left[\mathrm{m}^{2} / \mathrm{s}^{2}\right]$ $\varepsilon: \mathrm{k}$ の散逸率 $\left[\mathrm{m}^{2} / \mathrm{s}^{3}\right] \quad \mathrm{C}_{\mu}:$ モデル定数 $(=0.09[-])$

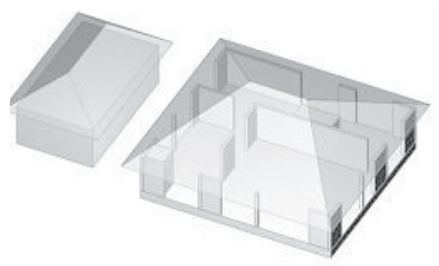

\begin{tabular}{|l|}
\hline \multicolumn{1}{|c|}{ 概要 } \\
\hline ・基淮モデル \\
（伝統的民家の原型を想定） \\
開口率 : $41.2 \mathrm{~m}^{2}$ \\
風向 : 16 方位 \\
\hline
\end{tabular}

1) Case 1

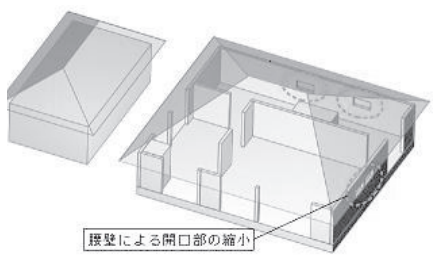

\begin{tabular}{|c|}
\hline \multicolumn{1}{|c|}{ 概要 } \\
\hline ・腰壁による開口部の縮小 \\
$($ 東·北面の開口部を縮小) \\
開口面積 $: 25.5 \mathrm{~m}^{2}$ \\
風向 $: 16$ 方位 \\
\hline
\end{tabular}

2) Case 2

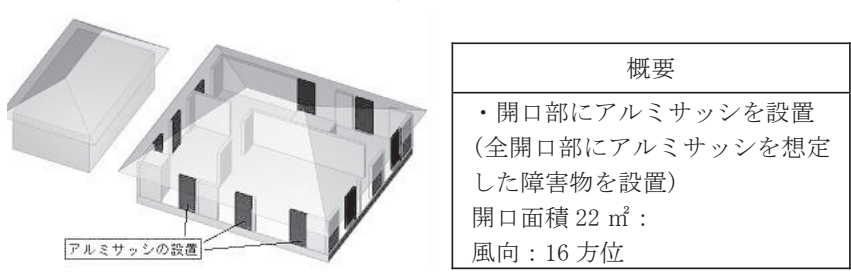

3) Case 3

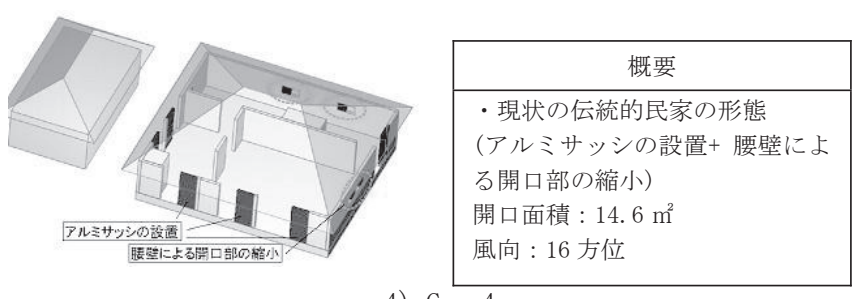

4) Case4

図 8 解析モデル (各ケース)

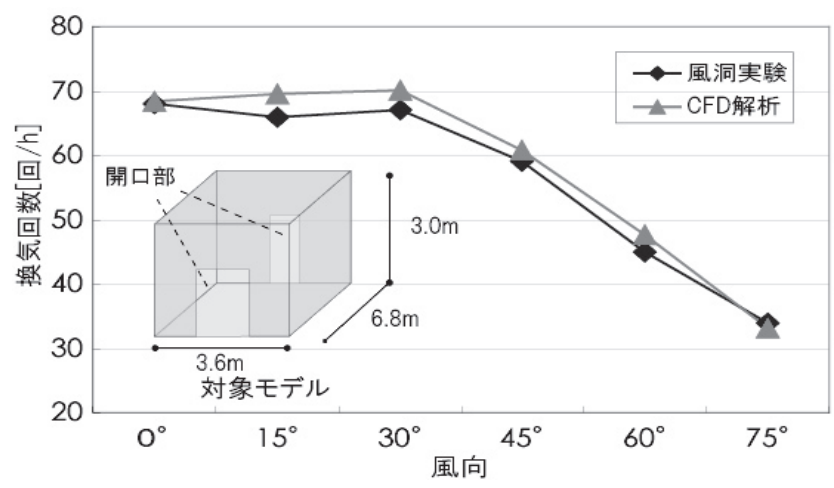

図 $9 \mathrm{CFD}$ 解析の予測精度の検証 
部屋 1 で過ごすことが多く、効果的な通風により涼感を得られるもの と考えられる。戦前は、部屋 2 の東側に対応寸る一番座も日中よく利 用されていたが 10)、こちらも部屋 1 同様に効果的に通風が得られて いたものと推察される。一方、裏座に位置する部屋 3 では気流、PFR $/ V_{p}$ 、 運動エネルギー共に小さい值となっており、特に裏座が風下側に位置 するため濃度場解析の際に一度解析領域から排出された污染物質が 再帰する（再度領域内に戻ってくる）可能性が高いため、PFR $/ \mathrm{V}_{\mathrm{p}}$ は著 しく低い值となっている注 10)。Case2 では腰壁設置の影響で風速值が Case 1 と比較して全体的に低くなっており、これに伴い $P F R / V_{p}$ 、運動 エネルギーも低下している。特に民家西側の開口面積の縮小により部 屋 2 の運動エネルギーの低下が顕著となる。Case 3 ではアルミサッシ の設置により全開口部の面積が Case 1 の $1 / 2$ 程度となっており、民家 内における外部風の影響範囲が狭くなる傾向となっている。 $\mathrm{PFR} / \mathrm{V}_{\mathrm{p}}$ 、 運動エネルギーの值は、各部屋ともC Case1 より低下しており、通風性 能の著しい低下が確認できる。Case4 は Case2、Case3 の両条件を考 慮したものであり、竹富島に現存する伝統的民家において多く見られ る様式である。室内風速分布は Case 3 と同様に外部風の影響範囲が狭 くなる傾向にあり、風速值も小さくなる。風速分布パターンから判断 すると、腰壁よりもアルミサッシの設置による影響が大きいものと推 察される。各室の $\mathrm{PFR} / \mathrm{V}_{\mathrm{p}}$ に関しては Case1 と比較すると平均的に $25 \%$ 程度、運動エネルギーに関しては50\%程度にまで大きく低下している。

\section{6-2 16 方位の風向下での結果 (各部屋別)}

図 $11 、 12$ に 16 方位の風向下での各ケースの $\mathrm{PFR} / \mathrm{V}_{\mathrm{p}}$ 、運動エネルギ 一の結果を部屋別にそれぞれ示す。いずれの部屋においても直接外部 風が流入寸る方位において $\mathrm{PFR} / \mathrm{V}_{\mathrm{p}}$ 、運動エネルギー共に高い傾向にあ る。各部屋、全風向において Case4 は Case 1 より $\mathrm{PFR} / \mathrm{V}_{\mathrm{p}}$ 、運動エネル ギー共にかなり小さい值であり、本来の伝統的民家(旧与那国家に対 応）と比較すると改修が施された現状の民家 (民家 A 及び B に対応) に おける通風性能の低さが確認できる。日中における主な居住空間であ る部屋 1 においては、Case 1 の場合、夏季の卓越風向である南風向時 に $\mathrm{PFR} / \mathrm{V}_{\mathrm{p}}$ 、運動エネルギー共に大きくなる。特に体感温度の低下能力 を表す運動エネルギーに関しては、E〜WSW の広範囲の風向に対して 大きな值を取る。

\section{6-3 16 方位の風向下での結果（民家全体）}

図 13 に民家全体における $\mathrm{PFR} / \mathrm{V}_{\mathrm{p}}$ 、運動エネルギーの算出結果を示 す。全ケースにおいて $\mathrm{PFR} / \mathrm{V}_{\mathrm{p}}$ 、運動エネルギー共に南〜東よりの風向 に対して大きな值となっていることが確認でき、特にCase1 において この傾向が顕著となる。南〜東よりの風向に対して通風性能が高くな る理由としては、開口部の設置位置や台所棟であるトーラを西側に配 している点等が考えられる。竹富島では年間を通して東よりの風が多

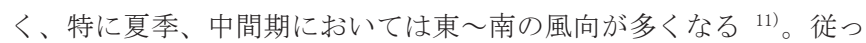
て、竹富島における伝統的民家は、夏季、中間期においてより室内に 風を導き入れるような造りとなっているものと推察される。しかし、 現状ではアルミサッシの設置や腰壁による開口部の縮小等、建築様式 にも変化がみられ、これに伴い室内通風性能も大きく低下しているも のと思われる。Case 1 と Case4 で比較すると、全風向を通じて PFR $/ V_{p}$ は 25\%程度、運動エネルギーに関しては 50\%程度にまで大きく低下し ている(南風向時と同様)。また室内の SET*に換算すると、Case4 では 室内通風性能の低下に伴い、Case 1 と比較して SET*が $1^{\circ} \mathrm{C}$ 程度高くな る 注 11)。4-1 の民家内の SET*の実測結果 (旧与那国家と民家 A の SET*

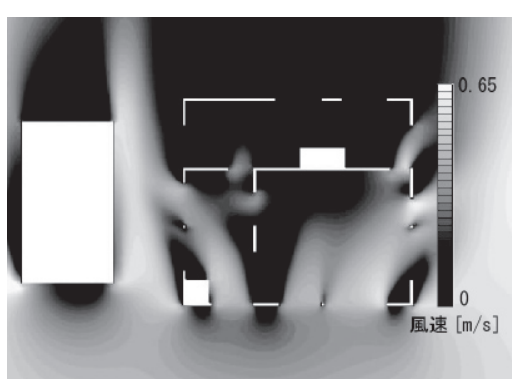

a）風速分布（床上 $1.1 \mathrm{~m}$ )

1) Case 1

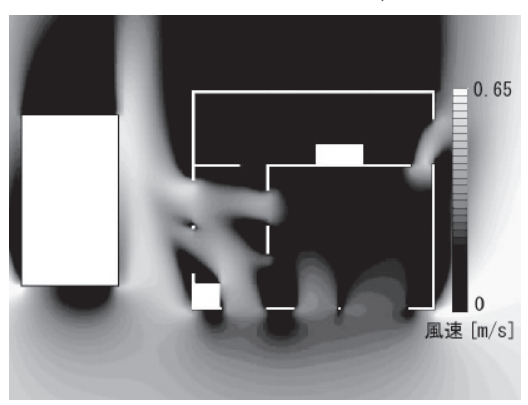

a）風速分布 (床上 $1.1 \mathrm{~m})$

2) Case 2

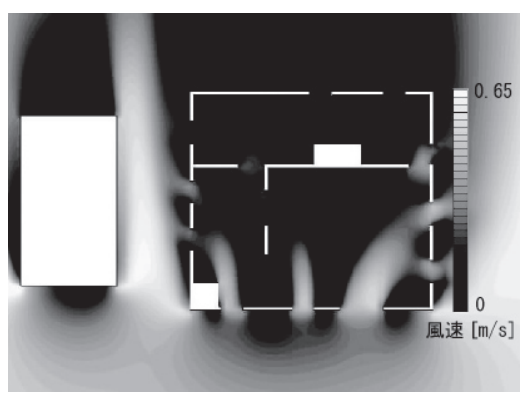

a）風速分布 (床上 $1.1 \mathrm{~m})$

3) Case 3

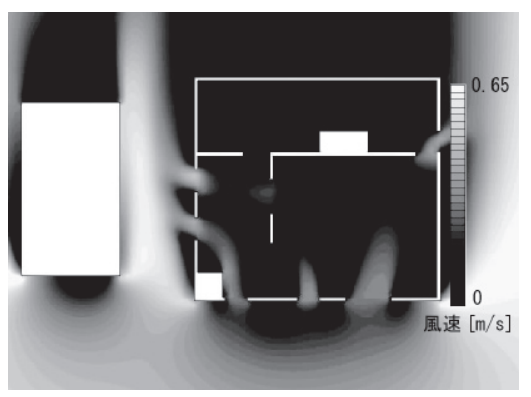

a）風速分布(床上 $1.1 \mathrm{~m})$

4) Case 4

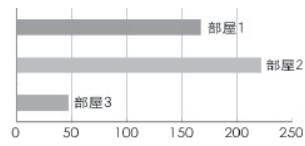

b) $\mathrm{PFR} / \mathrm{V}_{\mathrm{p}}[$ 回/h]

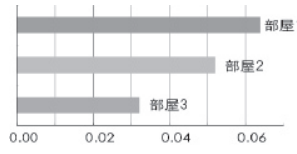

c）運動エネルギー $\left[\mathrm{m}^{2} / \mathrm{s}^{2}\right]$

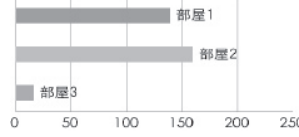

b) $\mathrm{PFR} / \mathrm{V}_{\mathrm{p}}[$ 回 $/ \mathrm{h}]$

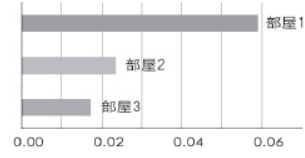

c）運動エネルギー $\left[\mathrm{m}^{2} / \mathrm{s}^{2}\right]$

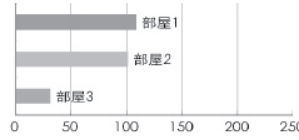

b) $\mathrm{PFR} / \mathrm{V}_{\mathrm{p}}[$ 回/h]

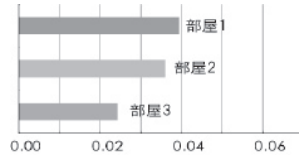

c）運動エネルギー $\left[\mathrm{m}^{2} / \mathrm{s}^{2}\right]$

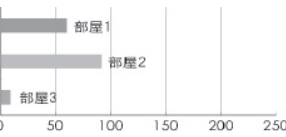

b) $\mathrm{PFR} / \mathrm{V}_{\mathrm{p}}[$ 回/h]

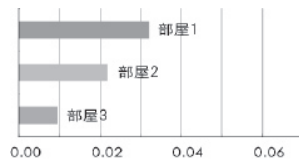

c）運動エネルギー $\left[\mathrm{m}^{2} / \mathrm{s}^{2}\right]$

図 10 解析結果(夏季卓越風向の南風向時)

の差異) と比較すると、民家 A では空開放時の開口面積は Case4 より も小さく、家具等の設置による圧力損失も大きいため、室内風速はよ り小さいものと推察される。図 5 に示寸通り、旧与那国家に対する民 
家 A の室内風速は 2 割程度であり、CFD 解析結果 (Case1 とCase4 の比 較)よりも差が影著となっている。このため、CFD 解析より推定した 通風性能の低下による SET*の上昇率は、実測結果と比較して若干低く なる傾向にあるが、概ね対応寸るものである。

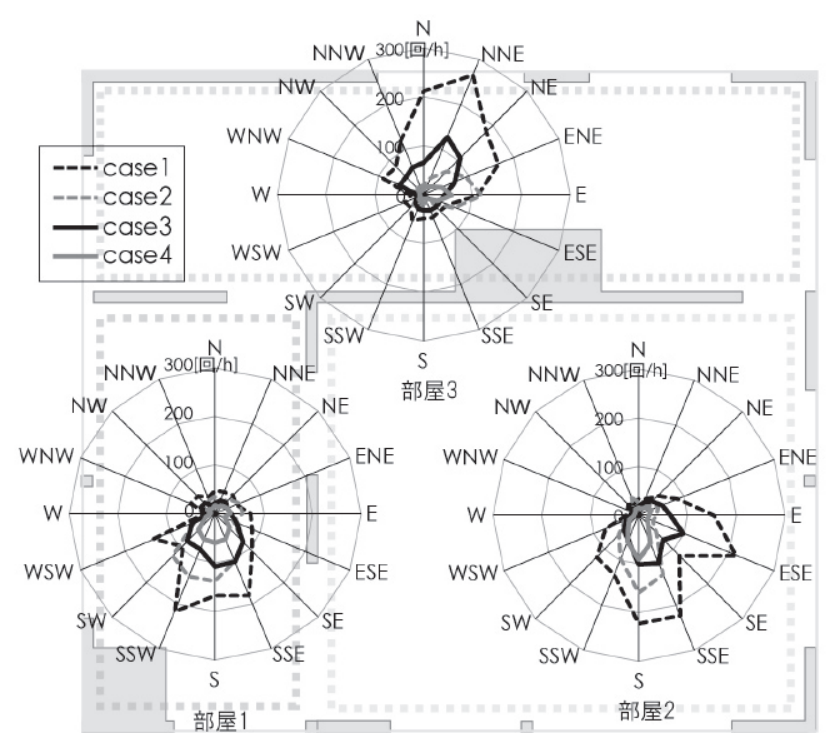

図 11 各室における $P F R / V_{p}$ [回/h]

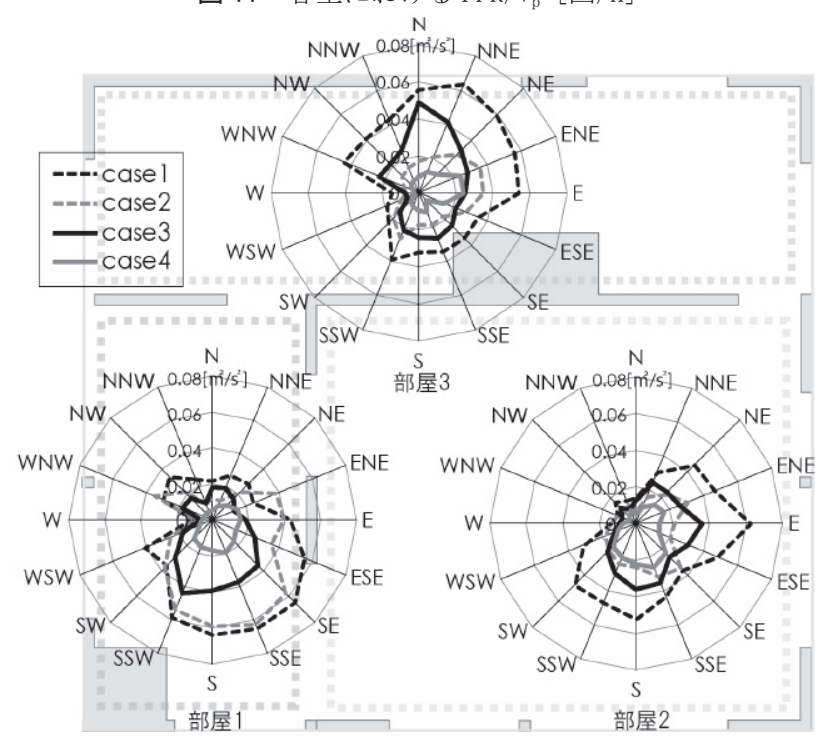

図 12 各室における運動エネルギー $\mathrm{KE}\left[\mathrm{m}^{2} / \mathrm{s}^{2}\right]$

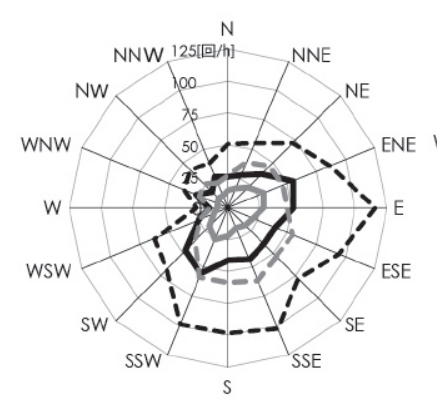

1) $\mathrm{PFR} / \mathrm{Vp}[$ 回/h]

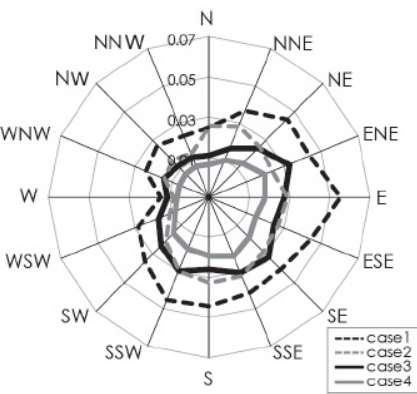

2) 運動エネルギー $\left[\mathrm{m}^{2} / \mathrm{s}^{2}\right]$
図 13 室内空間全体における $P F R / V_{p}$ [回/h]、 運動エネルギーKE $\left[\mathrm{m}^{2} / \mathrm{s}^{2}\right]$

\section{7. 結論}

本研究では、八重山群竹富集落における伝統的民家の室内温熱環境 の比較実測及び民家内の室内通風性状に関する CFD 解析により以下 の知見が得られた。

1）伝統的な民家形態を残す旧与那国家において伝統的な住まい方 （日中開放、夜間閉鎖）を再現した場合、改修等の施された現状の 民家と比較して日中の $\mathrm{SET}^{*}$ が $2^{\circ} \mathrm{C}$ ほど低くなった。現状の民家 $\mathrm{A}$ に おいて、同様な住まい方を再現しても、改修により開口面積が半減 している等の理由により十分な室内風速が得られておらず、開口部 を閉鎖している民家 B と日中の $\mathrm{SET}^{*} に$ 殆ど差がない。また体感温度 の低下には室内風速の寄与が最も大きい。

2) 全ての民家において夜間開口部を閉鎖した状況では、旧与那国家の 場合、他の民家と比較して建具の気密性能が低く夜間の換気量も多 いものと推察され、また内部発熱量も殆どないため、SET*夜間に おいても $1 \sim 2{ }^{\circ} \mathrm{C}$ 程度低くなる。夜間の開口部の開放による積極的な 外気導入によって更なる室内温度の低下が期待できる。

3) CFD 解析によると現状の民家は、アルミサッシや腰壁の設置に伴い 開口面積が半減し、結果的に本来の形状を有する伝統的民家と比較 して、全風向を通じて $P F R / V_{p}$ は 25\%程度、運動エネルギーKE に関し ては 50\%程度にまで大きく低下している可能性が示唆された。室内 の $\mathrm{SET}^{*}$ に換算すると、この $\mathrm{KE} の$ 低下は $\mathrm{SET}^{*} 1^{\circ} \mathrm{C}$ 程度の上昇に相当し、 4-1 の民家内の SET*の実測結果 (旧与那国家と民家 A の SET*の差異) と比較するとその上昇率は若干小さいが、概社対応するものである。 KE の低下には、特に腰壁よりもアルミサッシの設置による影響が大 きいものと推察された。

4）竹富島における伝統的民家は、夏季、中間期における卓越風向で ある東〜南の風向に対して室内へより風を取り入れる建築形態で あることが確認できた。

5）実測及びCFD 解析より、本来開放的であった伝統的民家の殆どは、 改修や生活様式の変化に伴い通風性能が低下し、結果として居住者 の温冷感に大きく影響していると考えられる注 ${ }^{12}$ 。

なお、今回の CFD 解析では民家単体のみを対象としており、石垣、 ヒンプン、フクギ、周辺建物等の影響を考慮していない。今後の検 討課題として位置づけている。

\section{謝辞}

本研究において実測調查に快く了承して頂いた各民家の皆様及び 竹富町教育委員会の関係者の方々に深く感謝する。本研究の一部は、 住友財団 2008 年度環境研究助成を受けて行ったものである。

\section{注}

注 1) 前回の測定 ${ }^{11}$ では、複数の民家内の温熱環境 4 要素の測定を行い SET ${ }^{*}$ 算 出を試みたが、全ての民家で同時測定を行っていないため、屋外環境の差 異の影響が懸念された。今回の実測では全ての民家で同時測定を行い、同 一屋外環境下での各民家の室内温熱環境の比較を行っている。

注 2）今回の実測で別途、民家の居住者に対して住まい方に関するヒアリング 調査を行っており、竹富集落では日中は砂埃の侵入を避けて開口部を閉じ る民家が多いことを確認している。砂埃による被害は、観光地化の進展に 伴い、人通りが増加したことや車等の使用により引き起こされているもの と考えられる。また本来の伝統的な民家では、室内一の通風に配慮して、 フクギの下枝を払っていたが、近年はそういった民家は殆ど見られない。

注 3) 本来の伝統的民家は、トーラが別棟で設けられていたため、人以外の内部 発熱は殆ど無かったものと推察される。発熱源としての居住者の有無が室 
内温熱環境入与える影響は小さいものと考えられるため、居住者のいない 旧与那国家では本来の伝統的民家に近い室内温熱環境を再現できている ものと推察される。

注 4) 9/3 の日中も閉鎖した状態で測定を行う予定であったが、管理の都合上、 一部開放せざるを得なかった。

注 5) 温熱環境評価指標 SET*は、暑暖域において湿度の影響を過大評価する傾向 にあり、特に高湿度環境下では SET*が実際の温冷感よりも高く算出される 可能性がある。

注 6) 民家 A、B 共に一般家庭と比較して家電製品も少なく、その利用頻度も低 い。特に民家 B に関しては、内部発熱として考えられる家電製品としては 冷蔵庫と照明機器程度であるが、換気・通風を殆ど行わないため、室温と SET*は他の民家と比較して高くなる傾向にある。

注 7) 平均放射温度に関しては、前報 (その 1） ${ }^{1)}$ 同様の傾向が確認できたため、 本報では省略する。

注 8) 平均值、変動幅の算出に当たっては、民家 A にて冷房を行っていた 20:00 〜24:00 のデータを除いている。民家 Aでは、冷房の使用時間も短く（入 眠時のみ）、また建物の熱容量も小さく、気密性能も低いため、冷房によ る室内 SET*への影響は概ね冷房使用時のみに限定されるものと推察され る。

注 9) 外気温度には旧与那国家民家の敷地内で測定した温度データを用いた。

注 10) 戦前から現在に至るまで裏座は就寝のための空間として利用されている が、竹富集落では夜間開口部を閉鎖する住まい方が一般的であるため、裏 座への通風性能はあまり重視されていないものと思われる。

注 11) 4-1 にて示した実測と同条件の着衣量 $(0.5 \mathrm{clo}$ ) 及び代謝量 $(1.0 \mathrm{met}$ )並び に $9 / 6$ の日中 $(6: 00 \sim 18: 00)$ の旧与那国家の平均的な室内の温度 $\left(30.3^{\circ} \mathrm{C}\right)$ 、 湿度 $(67.8 \%)$ 、平均放射温度 $\left(31.1^{\circ} \mathrm{C}\right)$ 、風速 $(0.27 \mathrm{~m} / \mathrm{s})$ を用いて算出した SET*が Case1 に対応するものと仮定し、Case4では室内風速のみ Case1 の 0.7 倍 (運動エネルギーKEの低減割合に対応) として算出した。

注 12）居住環境の水準が向上した現在、防犯性能が低い等の問題を有する伝統 的民家をそのまま普及させることは難しく、現状の民家の改修や生活様式 の変化は否定されるべきものではない。この点は、問題点を克服しうる新 しい民家のあり方（すまい方も含む）を模索する、もしくは伝統的民家を 要素技術に還元し、現代建築に活用する方法等を模索する必要がある。

\section{参考文献}

1）井上大嗣，白石靖幸，鄉田桃代：集落・民家スケールの暑熱環境緩和・防 風効果, 一八重山郡竹富島におけるパッシブ環境制御手法に関する研究 (そ の 1) - , 日本建築学会環境系論文集, N0. 638, pp. 465-472, 2009.4

2）辻幸伸，小玉祐一郎，武政孝治：伝統的民家にみられる室内熱環境調整機 能の評価, 日本建築学会大会学術講演梗概集 D-2, pp. 445-446, 1995.

3) 細江いずみ他: ヴァナキュラー建築の環境工学的研究 (その1), 連成数值 解析によるイグルーの屋内温熱環境評価, 日本建築学会大会学術講演梗概 集 D-2, pp. 565-566, 2005.

4）山中剛他：現地実測と CFD 解析によるインドネシアの高床式住居の屋内温 熱環境評価, 日本建築学会関東支部研究報告集 I, 材料・施工・構造・防 火・環境工学 (79), pp. 753-756, 2009.

5）観光資源保護財団：竹富島の民家と集落 観光保全と観光活動に関する報 告, 日本ナショナルトラスト, 1976.

6) Kato M. and Launder B.E. : "The modeling of turbulent flow around stationary and vibrating square cylinders", Ninth symposium on turbulent shear flows, 10-4, 1993.

7）村上周三他：トレーサーガス法を利用した住宅の自然通風に関する風洞実 験 ガイドベーン, バルコニー, 室内外障害物等が通風に及ぼす影響に関す る検討, 日本風工学会誌, N0.33, pp. 1-8, 1987.

8）卜震他：通風換気性能に関する超過確率に基づく風環境評価法の提案とそ の空堀モデルへの適用, 市街地の風環境に関する研究 (その1), 日本建築学 会環境系論文集，N0.629，pp. 903-910，2008.7

9) 村上周三他 : $k-\varepsilon$ モデルにおける建物風上の $\mathrm{k}$ の過大評価モデルの改良, 第 10 回風工学シンポジウム論文報告集, pp. 199-204, 1988.

10) 斎藤輝二, 横田望 : 住宅・居住様式の研究 8-2, (2) 竹富島・トウラ分棟型 住宅の居住様式, 日本建築学会大会学術講演梗概集 E, pp. 1227-1228, 1993.
11) 日本建築学会：拡張アメダス気象データ, 2000.

12) 井上大嗣, 白石靖幸, 中野淳太 : 八重山・竹富島におけるパッシブ環境制 御手法に関する研究，（その 3）建築様式、住まい方の変化が室内温熱環境 に及ぼす影響, 日本建築学会九州支部研究報告, 第 48 号環境系, pp. 125-128, 2009.

13) 中山翔太, 井上大嗣, 白石靖幸 : 八重山・竹富島におけるパッシブ環境制 御手法に関する研究，（その 4) CFD 解析による伝統的民家の室内通風性状 の評価, 日本建築学会九州支部研究報告, 第 48 号 環境系, pp. 129-132, 2009.

(2010年 2 月 3 日原稿受理, 2010年10月29日採用決定） 